\title{
Stauffer's Syndrome: A Rare Paraneoplastic Syndrome with Renal Cell Carcinoma
}

\begin{abstract}
An elderly male patient presented with cholestatic jaundice and weight loss. On evaluation, he was found to have left renal mass and hepatomegaly. Diagnosis of Stauffer's syndrome was confirmed based on his clinical history, biochemical evaluation, and liver biopsy. Resolution of jaundice was noted after removal of the renal mass.
\end{abstract}

Keywords: Cholestasis, jaundice, paraneoplastic, renal

\section{Introduction}

Nonmetastatic nephrogenic hepatic dysfunction syndrome (Stauffer's syndrome) is a paraneoplastic manifestation that often appears as the initial clinical presentation of renal cell carcinoma, bronchogenic carcinoma, leiomyosarcoma, and prostate adenocarcinoma. ${ }^{[1-3]}$ Although jaundice has rarely been described with this syndrome, a few case reports have highlighted a variant of the syndrome with deep icterus. ${ }^{[4,5]}$

\section{Case Report}

A 63-year-old male presented with a history of yellowish discoloration of eyes and urine, generalized itching, and weight loss of $10 \mathrm{~kg}$ over last 1 month. On clinical examination, he was afebrile, deeply icteric, and had palpable liver. His investigations showed hemoglobin $8.4 \mathrm{gm} \%$, total count of $7070 / \mathrm{Cu} . \mathrm{mm}$, and platelets of 191000/cu.mm. Serum bilirubin was $35.8 \mathrm{mg} /$ $\mathrm{dl}$ (direct bilirubin $-32.10 \mathrm{mg} / \mathrm{dl}$ ), aspartate aminotransferase - $42 \mathrm{IU} / \mathrm{ml}$, alanine aminotransferase - $58 \mathrm{IU} / \mathrm{ml}$, international normalized ratio - 1.14, and serum creatinine $-1.8 \mathrm{mg} / \mathrm{dl}$. Serological tests for hepatitis B and C, HIV, and autoimmune liver diseases were negative. Serum ceruloplasmin levels and ferritin levels were within normal range. Contrast-enhanced computed tomography abdomen showed a $5.3 \mathrm{~cm} \times 1 \mathrm{~cm} \times 4.8 \mathrm{~cm}$ left renal mass, hepatomegaly, and no evidence of biliary dilatation or ascites. Liver biopsy showed

This is an open access journal, and articles are distributed under the terms of the Creative Commons Attribution-NonCommercial-ShareAlike 4.0 License, which allows others to remix, tweak, and build upon the work non-commercially, as long as appropriate credit is given and the new creations are licensed under the identical terms.

For reprints contact: reprints@medknow.com mild portal fibrosis with hepato canalicular bilirubinomatosis and lobular inflammation. The possibility of cholestatic jaundice due to paraneoplastic manifestation of renal cell carcinoma was considered. The patient was managed by therapeutic plasma exchange for severe pruritus in the preoperative period, and he underwent laparoscopic left radical nephrectomy. The surgical specimen showed clear cell renal cell carcinoma with perinephric fat, hilar sinus fat, hilar vessels, and ureter free of tumor invasion (Fuhrman Nuclear Grade II). Postoperatively, he had gradual fall in the bilirubin values over a period of 4 weeks.

\section{Discussion}

Renal cell carcinoma accounts for $2 \%$ of all cancers and $2 \%$ of all deaths due to neoplasms. ${ }^{[6]}$ It is associated with multiple systemic and paraneoplastic manifestations which may hide the true diagnosis until full evaluation. ${ }^{[7]}$ Cholestasis is malignancies which may be related to compression of biliary tree by lymph nodes, hepatic infiltration by the malignant cells, metastasis, side effects of drugs, or rarely due to paraneoplastic syndromes. Stauffer's syndrome, originally described in 1961 by M. H. Stauffer, is characterized by elevated alkaline phosphatase, erythrocyte sedimentation rate, $\alpha$-2-globulin, and $\gamma$-glutamyl transferase, thrombocytosis, prolongation of prothrombin time, and hepatosplenomegaly, in the absence of hepatic metastasis. ${ }^{[8]}$ Interleukin-6 overexpression by the primary tumor has

\footnotetext{
How to cite this article: Jain M, Varghese J, Muruganandham KM, Venkataraman J. Stauffer's syndrome: A rare paraneoplastic syndrome with renal cell carcinoma. Indian J Med Paediatr Oncol 2018;39:546-7.
}

\section{Mayank Jain, Joy Varghese ${ }^{1}$, K M Muruganandham², Jayanthi Venkataraman}

\author{
Departments of \\ Gastroenterology, ${ }^{1}$ Hepatology \\ and ${ }^{2}$ Urology, Gleneagles \\ Global Health City, Chennai, \\ Tamil Nadu, India
}

Address for correspondence: Dr. Mayank Jain, Department of Gastroenterology, Gleneagles Global Health City, Chennai - 600 100, Tamil Nadu, India.

E-mail: mayank4670@ rediffmail.com

Access this article online

Website: www.ijmpo.org

DOI: 10.4103/ijmpo.ijmpo_97_17 Quick Response Code:

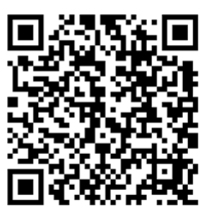


been implicated for the syndrome. ${ }^{[9]}$ Cholestatic variants of the syndrome have been described in literature; authors recommend that renal cell carcinoma should be included in the differential diagnosis of both icteric and anicteric cholestatic liver disease. ${ }^{[4]}$

Our patient presented with cholestatic jaundice, itching, hepatomegaly, and no radiological evidence of liver metastases. On histopathological analysis, there was no renal vascular involvement. His clinical improvement after surgery confirms that his cholestatic jaundice was secondary to renal cell carcinoma. This case highlights a rare paraneoplastic syndrome associated with renal cell carcinoma.

\section{Acknowledgments}

We acknowledge the help of Consultant Pathologist Dr. Mukul Vij and Dr. Deepti Sachan, Consultant - Department of Transfusion Medicine in the management of the patient.

\section{Financial support and sponsorship}

Nil.

\section{Conflicts of interest}

There are no conflicts of interest.

\section{References}

1. Sharara AI, Panella TJ, Fitz JG. Paraneoplastic hepatopathy associated with soft tissue sarcoma. Gastroenterology 1992;103:330-2.

2. Karakolios A, Kasapis C, Kallinikidis T, Kalpidis P, Grigoriadis N. Cholestatic jaundice as a paraneoplastic manifestation of prostate adenocarcinoma. Clin Gastroenterol Hepatol 2003;1:480-3.

3. Saintigny P, Spano JP, Tcherakian F, Pailler MC, Breau JL. Non-metastatic intrahepatic cholestasis associated with bronchial adenocarcinoma. Ann Med Interne (Paris) 2003;154:171-5.

4. Morla D, Alazemi S, Lichtstein D. Stauffer's syndrome variant with cholestatic jaundice: A case report. J Gen Intern Med 2006;21:C11-3.

5. Dourakis SP, Sinani C, Deutsch M, Dimitriadou E, Hadziyannis SJ. Cholestatic jaundice as a paraneoplastic manifestation of renal cell carcinoma. Eur J Gastroenterol Hepatol 1997;9:311-4.

6. Jemal A, Tiwari RC, Murray T, Ghafoor A, Samuels A, Ward E, et al. Cancer statistics, 2004. CA Cancer J Clin 2004;54:8-29.

7. Gold PJ, Fefer A, Thompson JA. Paraneoplastic manifestations of renal cell carcinoma. Semin Urol Oncol 1996;14:216-22.

8. Stauffer MH. Nephrogenic hepatomegaly. Gastroenterology 1961;40:694.

9. Blay JY, Rossi JF, Wijdenes J, Menetrier-Caux C, Schemann S, Négrier S, et al. Role of interleukin-6 in the paraneoplastic inflammatory syndrome associated with renal-cell carcinoma. Int J Cancer 1997;72:424-30. 